\title{
TOWARD A CLASS ANALYSIS OF THE INDONESIAN MILITARY BUREAUCRATIC STATE*
}

\author{
Richard Robison
}

Contrary to the expectations of modernization and developmentalist theorists, the historical experiences of Europe and North America have not been reproduced in the postcolonial societies of the Third World. 1 The spread of capitalism has not been accompanied by the emergence of liberal democratic bourgeois states. Instead, the development of capitalism has resulted in the growth of military bureaucratic states.

Nowhere are these developments more clearly illustrated than in the case of Indonesia. Since the formal transfer of sovereignty in 1949 and, in particular, with the acceleration of large-scale foreign corporate investment that began in 1967 , the entrenchment of the military bureaucratic state has been intensified. Explanations of the formation of elites and of the state in Indonesia have generally been based on such factors as ideology, political culture, or the structure of palace politics. It is my contention, however, that a more fundamental explanation 1 ies in the capitalist transformation of the Indonesian economy.

While it is true that the ownership of capital in Indonesia resides primarily with foreigners and a domestic Chinese bourgeoisie, neither group can aspire to the position of ruling class in the full social and political meaning of the term. We must therefore turn our attention to the structure of asli social and political power, above a11 in New Order Indonesia. I will argue that capitalism has produced four distinct types of bourgeoisie in contemporary Indonesia and that power struggles under the New Order reflect the competing interests of these groups.

*This paper summarizes one of the major themes in R. Robison, "Capitalism and the Bureaucratic State in Indonesia: 1965-1975" (Ph.D. thesis, Sydney University, 1978), which contains extensive data on the formation and structure of the asli (indigenous Indonesian) component of the corporate sector in Indonesia and which provides detailed substantiation of various arguments concerning capitalism and the social base of power and the state under the New Order.

${ }^{1}$ Research on Third World economies in the 1950s and $1960 \mathrm{~s}$ was dominated by an American school of political scientists, sociologists, and economists who used a comparative approach and whose intellectual origins lay within the structural-functional view of social structure and social change. Their theses on social, economic, and political change in the capitalist economies of the Third World were predicated on the assumption that the historical experience of the West would be duplicated there. This would be achieved as a consequence of the adoption of modernization policies which would infuse Western capital, technology, values, attitudes, and political structure, thereby creating a capitalist society and a bourgeois state. Prominent within this broad school were Joseph LaPalombara, Myron Wiener, Lucian Pye, Bert Hoselitz, and W. W. Rostow. 
First, there is an asli (Muslim) merchant bourgeoisie concentrated in small-scale trade and commodity production. The product of an earlier, merchant capitalism, this bourgeoisie has remained on the periphery of asli political power since the 1920s. Its economic base has steadily declined with the rise of capital-and technology-intensive foreign investment in mining and import substitution manufacture.

Second, an alliance of civil bureaucrats, students, and intellectuals has emerged, largely as the product of the development of a regularized, "legal" state capitalism. The social and political power of this alliance has depended upon the extension of the state sector, which provides special opportunities for technocrats, planners, managers, and associated intellectuals. Most recently, this group has suffered difficulties as the development of state capitalism foundered on the neopatrimonial nature of the bureaucratic state and its integration with foreign and Chinese capital.

Third, the military bureaucracy, from the national to the regional level, has secured a base of economic power deriving not from private ownership of capital but from the appropriating power of bureaucratic office which enables particular factions and commands to control access to the market. I will refer to this military power-group as bureaucratic capitalists. Occupying the key centers of political power within a neopatrimonial mercantilist state, they have been able to secure a share of the profit generated by foreign and domestic Chinese capital.

Finally, a client asli bourgeoisie has emerged, outside the bureaucratic apparatus, but dependent on it and on foreign capital.

Having delimited these four groups, I will now consider the history and character of each in more detail.

\section{The Decline of the Muslim Merchant Bourgeoisie}

It is best to deal first with the decline of the traditional Muslim trading, commodity-producing, and land-owning bourgeoisie because scholars once quite widely assumed that it would be stimulated by the accelerated expansion of the capitalist economy. Much of the research concerning the social and economic structure of postcolonial Indonesia has attempted to grapple with the failure of these expectations. ${ }^{2}$ While the proffered explanations involve supposed cultural obstacles to the full acceptance of the capitalist revolution, closer analysis suggests that the decline of this merchant bourgeoisie is a direct structural consequence of the type of capitalism which has been imposed upon Indonesia.

2Probably the best-known attempt to understand the failure of a traditional asli bourgeoisie is Clifford Geertz, Peddlers and Princes (Chicago: University of Chicago Press, 1963). Indonesian writers have also looked at the problem. See Arifin M. Siregar, "Indonesian Entrepreneurs," Asian Survey, 9 (1969), pp. 343-58. Sri Edi Swasono, "Some Notes on the Nurturing of the Indonesian Entrepreneur," Indonesian Quarterly, 1 (1973), pp. 51-64. The important point about these works and most others on the subject is their interpretation of failure as cultural resistance to capitalism. 
Throughout the colonial period, Dutch power secured for the Dutch trading houses and, later on, banks, estates, and shipping and mining companies, effective monopolies in international trade and large-scale investment. Chinese merchants were cultivated as intermediaries for the domestic Indonesian market. This structure excluded the as $1 \mathrm{i}$ merchant bourgeoisie who, without the protection of the state, remained locked into small-scale trading and commodity production in rural areas and small towns, and who fought a largely unsuccessful rearguard action against the incursions of Chinese capital, particularly in the fields of textile, batik, and kretek production. 3 Their continuing economic decline in the early decades of the twentieth century was paralleled in the political sphere with the disintegration of the Sarekat Islam, which initially represented their nationalist and anti-Chinese sentiments. From the middle $1920 \mathrm{~s}$, the nationalist movement fell increasingly under the domination of secular politicians originating in the priyayi administrative class and intellectually shaped by Western liberalism or Marxism. ${ }^{4}$ The as 1 i Muslim bourgeoisie never regained its initial political edge during the colonial period and fared no better after Independence.

For although the Dutch were unable directly to retain political power after 1949, they continued to exert heavy influence on Indonesia's economy and political 1 ife. Together with the Chinese, they continued to dominate investment in the medium-and large-scale sectors of the economy. The asli merchant bourgeoisie commanded neither the economic nor, more importantly, the political power to enable them to replace the Dutch. Political power was secured by secular elites whose power base lay initially within mass-based parties and, from 1957 onwards, increasingly within the military.

The political parties which led the governments of the early 1950s, while formally espousing ideologies of a socialist and nationalist character, quickly came to the conclusion that any rapid move from a colonial to a national economy would create disruption on a scale that they could not manage and thus were unwilling to confront. ${ }^{5}$ Where they did attempt to indigenize some sectors of the economy, they did so by developing state capitalism rather than by seriously supporting any asli entrepreneurial bourgeoisie. The Benteng program of 1950-55,

${ }^{3}$ The economic and political struggle between traditional asli commodity-producers and Chinese capital has been dealt with to varying degrees in W. F. Wertheim, Indonesian Society in Transition (The Hague: Van Hoeve, 1956), esp. ch. 5; and R. Van Niel, The Emergence of the Modern Indonesian Elite (The Hague: Van Hoeve, 1960).

${ }^{4}$ Legge identifies several major streams of nationalism: cultural nationalism, Islamic nationalism, communism, and secular nationalism. With the splitting of Sarekat Islam in the early 1920 s and the suppression of the communist uprisings in 1926-27, the field was left to Dutch-educated Indonesian intellectuals drawn from the professions and the bureaucracy. See John D. Legge, Indonesia (Sydney: Prentice Hall, 1977), ch. 6 .

${ }^{5}$ The rapid accommodation of such men as Sjafrudin Prawiranegara, Wilopo, and Dr. Sumitro to the continued existence of a foreign-dominated economy is best documented in John 0. Sutter, Indonesianisasi: Politics in a Changing Economy, 1940-1955, Southeast Asia Program Data Paper (Ithaca: Cornell University, 1959), esp. pp. 11781188 ; and $\mathrm{K}$. Thomas and $\mathrm{J}$. Panglaykim, Indonesia: The Effect of Past Policies and President Suharto's Plans for the Future (Sydney: Committee for Economic Development of Australia, 1973), esp. ch. 2. 
which sought to protect and subsidize asli businessmen through preferential allocation of import licenses, did nothing to develop a powerful asli bourgeoisie because, indeed, that was never its basic objective.6 Licenses, state bank credits, government contracts, and other concessions were seen by virtually all political factions as the spoils of power. They were not allocated to the asli business community according to publicly formulated and economic criteria for eligibility, but were distributed to "business groupings" on the basis of political association. Consequently, the vast majority of Benteng importers were political clients rather than members of a preexisting asli merchant bourgeoisie. Many, indeed, were simply license brokers who sold their politically derived concessions to Chinese and foreign businessmen rather than using them to establish genuine business ventures.7

A few of the asli merchant bourgeoisie did benefit from the Benteng policy. Men like Dasaad, H. A. Ghany Aziz, Rahman Tamin, and Djohan Djohar rose to national prominence with the protection and subsidies they secured from the state. ${ }^{\circ}$ Their success, however, was achieved not by business skills so much as through alliances with those with power to allocate concessions. And because political factions rose and fell from power with great rapidity, the situation of as 1 importing groups was one of chronic insecurity.

From 1955 on, the position of the asli bourgeoisie worsened. The Benteng policy was discontinued, and the group's main sources of political protection--the Masjumi party, the PSI (Indonesian Socialist Party), and the right wing of the PNI (Indonesian Nationalist Party)-lost influence. ${ }^{9}$ When Sukarno began his attempt to build a national economy in 1957, he turned to state capitalism as the most appropriate policy instrument. 10

While the turn towards state capitalism was reversed under the New Order, the asli merchant bourgeoisie did not benefit from the

'Probably the best, detailed summary of the Benteng experiment is to be found in R. Anspach, "Indonesia," in F. Golay et al., eds., Underdevelopment and Economic Nationalism in Southeast Asia (Ithaca: Cornell University Press, 1969), pp. 111-201. Sutter, and Thomas and Panglaykim also provide valuable analyses.

7 In mid-1953, the number of Benteng importers was cut by screening from 7,000 to 3,000 . In August 1954, the Central Office of Imports estimated that 90 percent of registered national importers were not bona fide, and the Minister of Economic Affairs, Iskaq, acknowledged that licenses were being marketed at 200-250 percent of their nominal value. In December 1955, Minister of Economic Affairs Rooseno ordered a new screening, which again revealed an extremely low (10 percent) proportion of genuine businessmen among the "national importers." See Sutter, Indonesianisasi, pp. 1017-35.

${ }^{8} \mathrm{~A} 11$ of these were Sumatran traders who had risen to national prominence in the 1930s. Benteng import licenses contributed significantly to the expansion of their operations in the early 1950s. For a detailed analysis of this group see Robison, "Capitalism," ch. 5.

9The Masjumi and the PSI were suppressed in 1960 because of their associations with the PRRI/Permesta rebellions. Within the PNI, power shifted from figures like Wilopo to more left-leaning and Sukarnoist factions. The various military factions became the major new source of patronage in the period 1957-65.

${ }^{10}$ Thomas and Panglaykim, Indonesia, is a comprehensive source for this period. See also T. K. Tan, ed., Sukarno's Guided Indonesia (Brisbane: Jacaranda Press, 1967). 
renewed emphasis on the private sector. The economic strategies of the New Order technocrats aimed at maximum economic growth through the infusion of large-scale foreign capital and technology. ${ }^{11}$ The foreign investment law (Peraturan Modal Asing, PMA), introduced in 1967, gave generous tax and import duty concessions to foreign investors and quickly allowed foreign capital to dominate the fields of forestry, mining, and import substitution manufacture.12 The policymakers opposed any policies of subsidy and protection for asli businessmen, since they assumed that the infusion of foreign capital and technology would flow down to asli producers and stimulate their development through the market. In fact, the opposite occurred. There has been a significant movement of large-scale Chinese and foreign capital into sectors which were traditionally the main preserve of asli merchants, such as batik, textiles, beverages, foodstuffs, and kretek cigarettes. The Domestic Investment Law of 1968 (Peraturan Modal Dalam Negeri, PMDN), designed to rectify the damage inflicted on domestic investors by the Foreign Investment Law of the previous year, in the end largely benefited the Chinese business community. Because its provisions applied only to new investments, it did not assist the majority of asli merchants and commodity producers whose capital was largely tied up in stock and plant and who, with no access to foreign sources of capital, had been hard hit by the policies of financial retrenchment introduced between 1965 and $1968 .{ }^{13}$ It is generally estimated that the asli share of investment under the Domestic Investment Law is about 25 percent and that the share of this actually held by the old asli bourgeoisie is decreasing. ${ }^{14}$

Although the New Order authorities emasculated preexisting autonomous asli business groupings and operated the only officially sanctioned business association, Kadin, virtually as a government department, the disintegration of asli business enterprise, especially in the fields of textiles, batik, foodstuffs, and kretek, generated considerable political unrest. The government was therefore reluctantly forced to introduce some measures of protection. In 1970 and 1971, government agencies were established to insure that bank credits be given to asli

${ }^{11}$ The economic philosophy of the Bappenas (Badan Perencanaan dan Pembangunan Nasional, National Planning and Development Board) technocrats is to be found in a wide variety of writings. Probably the most comprehensive are Mohammad Sadli, "Reflections on Boeke's Theory of Dualistic Economies," in Bruce Glassburner, ed., The Economy of Indonesia (Ithaca: Cornell University Press, 1971), pp. 99-123; and Emil Salim, Tulisan-tulisan (Jakarta: Bappenas, 1971).

12Repub1ic of Indonesia, Act No. 1, 1967 (January 1), Peraturan Modal Asing; Republic of Indonesia, Act No. 6, 1968 (July 3), Peraturan Modal DaZam Negeri.

${ }^{13}$ The damaging effects of this aspect of the Domestic Investment Law were spespecifically mentioned by a large number of the asli businessmen interviewed by the writer. They argued that the major obstacle to expansion and survival was lack of capital. Not only were they unable to obtain cheap money from foreign sources, but they were only able to secure about 20 percent of state bank investment credit. See Robison, "Capitalism," ch. 4-5.

${ }^{14}$ The most detailed attempt to assess the asli share of capital investment in Indonesia is to be found in Pande R. Silalahi, "Perimbangan Modal Swasta Nasional di Indonesia," Analisa Masalah-Masalah Internasional, 3, 5 (1974), pp. 9-24. News on the decline of textile and batik producers is found in the Jakarta press throughout the period 1970-74, especially in Nusantara. 
businessmen and to provide investment credit and advice where the applicant would not normally be eligible for bank loans. ${ }^{15}$ Following the disturbances of January 1974, the government introduced measures requiring foreign investors to take only asli partners in joint ventures and reserving state bank credit for asli businessmen. ${ }^{16}$ Yet as in the case of the Benteng policy, the asli who have actually benefited from this virtual monopoly on state bank credit and joint venture partnerships have been officials and their clients. Regulations introduced in 1974 to transfer equity in joint ventures from foreign and Chinese partners to asli counterparts have proved basically unworkable, simply because the capital is not available.17

Traditional asli merchants and commodity producers confront two major sources of economic and political power in contemporary Indonesia. First, they face the economic planners of the New Order, who, continuing the technocratic traditions of the PSI and right-wing PNI planners of the $1950 \mathrm{~s}$, are primarily interested in maximizing economic growth. In their view this is best induced by foreign capital investment and the infusion of foreign technology rather than by protection and subsidy of an asli bourgeoisie lacking sizeable capital and up-todate technology and corporate organization. Because of their axiomatic assumption that foreign capital investment ought to stimulate asli business, the accelerated collapse of asli enterprise has been interpreted as the result of cultural resistance to capitalist penetration rather than an inherent structural consequence of foreign investment itself. Accordingly, the technocrats have devoted little attention to structural protection of asli business or to accommodating their deve1opment strategies to the potential of asli capital. Instead, emphasis has been placed on establishing educational programs designed to provide asli businessmen with management skills and the proper entrepreneurial values and attitudes.18

Second, they are up against the politico-bureaucratic elites, who have appropriated the bulk of the available licenses, contracts, credit,

15Up to the end of 1973, state banks had given only 17 percent of available investment credit to asli businessmen; "Perkiraan Kebutuhan Dana Untuk Menunjang Program Peningkatan Usaha Pribuni Dalam PMN dan PMDN" (Jakarta: Bappenas, February 1974). Obstacles to asli access to bank credit are discussed in detail in the article "Kredit PMDN--Antara Koneksi dan Investasi," Tempo, December 9, 1972. The agencies established by the government were P.T. Askrindo and P.T. Bahana.

${ }^{16}$ See Presidential Statement to Governors' Working Conference, Jakarta, February 6, 1974, reported in Kompas, February 7, 1974, and Business News, February 8, 1974 .

${ }^{17}$ According to Ir. Suhud, Chairman of the Capital Investment Board (Badan Koordinasi Penanaman Modal Asing, BKPMA), achieving the targets set for transfer of equity would involve the expenditure of $\mathrm{Rp}$. 100 billion per year for ten years. (Statement reported in Kompas, February 23, 1974.)

${ }^{18}$ The ideas of the American psychologist D. McClelland have been especially popular with government management institutes and university economics departments. McClelland believes that "third world" businessmen are not so much confronted with such structural obstacles as lack of capital, as a lack of achievement motivation and entrepreneurial values. At least two government programs have been established to "transform" Indonesian entrepreneurs. See Sinar Harapan, December 12, 1974, and Tempo, February 22, 1975, for details and comments. 
and other concessions to further their integration with foreign capital as importers and joint venture partners. As early as 1958, $\mathrm{H}$. $\mathrm{O}$. Schmitt drew attention to the conflict between the Outer Island exportoriented traders, whose interests lay in deflationary policies, and the bureaucratic importers on Java, whose interests lay in inflation. ${ }^{19}$ In New Order Indonesia, the interests of these two groups clash again over the question of foreign capital. While the decline of asli commodityproducers (exporters) is accelerated by the penetration of capital-intensive foreign and, to a lesser extent, Chinese investment, powerful factions and families within the politico-bureaucratic elite benefit from this process as (1argely importing) joint venture partners.20

The largely Muslim asli merchant bourgeoisie have, in a very real sense, been overtaken by history. They are the victims of the penetration of foreign and Chinese capitalists with overwhelming financial and technological resources. They are also the victims of a tradition of politico-bureaucratic power (originating in the precolonial agrarian kingdoms of Java) which has successfully integrated itself into the neocolonialist structures of post-1949 Indonesia.

\section{State Capitalism}

It will be remembered that the early economic policymakers of the PSI, the PNI, and the Masjumi were all to some extent influenced by socialist ideals. Although many of these ideals were diluted when these leaders were faced with the practical difficulties of dismantling a colonial economy, they were never entirely abandoned. In their search for ways to break the Dutch economic stranglehold, however, they turned less to the asli bourgeoisie than to the national state itself as a means of establishing some degree of economic autonomy. Between 1949 and 1957, a state-owned central banking system was established, and some state corporations began operating in the fields of trade and manufacture. Finance Ministers such as Sumitro and Iskaq were particularly active in using the power of the state to increase national control of strategic sectors of the economy. 21 This tendency rapidly increased in the period of Guided Democracy.

Following the nationalization of Dutch corporate holdings in Indonesia in 1957-58, state corporations were established to take over the

${ }^{19}$ Hans 0. Schmitt, "Post-colonial Politics: A Suggested Interpretation of the Indonesian Experience, 1950-1958," The Australian Journal of Politics and History, 9,2 (November 1963), pp. 176-83.

${ }^{20}$ The resurgence of private corporate investment in Indonesia after 1967 has produced the joint venture and the local partner as major features of big business. In my analysis of major business groups under the New Order, I found that asli participation in big business was dominated by officials, their families, and their associates and consisted in accumulating minority partnerships with foreign or Chinese partners. Traditional asli bourgeoisie participated in very few large joint ventures and retained none of the wholly-owned large-scale enterprises which existed before 1965. See Robison, "Capitalism," Appendix B.

21 Iskaq was the most rigorous enforcer of the Benteng program which was, in essence, an attempt to use the power of the state to alter the structure and composition of the bourgeoisie in Indonesia. Under Sumitro the state was mainly active in banking and long-term central economic planning. See Thomas and Panglaykim, Indonesia, pp. 47-49. 
confiscated Dutch interests in shipping, agricultural estates, trade, and, to a lesser extent, manufacturing. State capitalism became the central focus of the Indonesian Guided Economy.22

But with the overthrow of Sukarno and the establishment of the New Order of General Suharto after 1965, there began a major withdrawal from these policies. The American-trained economic strategists of the New Order moved to reestablish the preeminence of private enterprise and foreign capital investment. By 1975, foreign corporations were once again dominant in mining, forestry, and, increasingly, in the import substitution sector, especially textiles.23

Nonetheless, several state corporations continue to sit astride strategic economic sectors. These include Pertamina (oil), Aneka Tambang and Timah (mining), Perkebunan (agricultural estates), and Gresik, Gaya, and others in the field of manufacturing. There appear to be two major reasons for their survival. First, the Bappenas planners still retain something of the old PSI approach in that they regard the participation of the state in strategic sectors of the economy as essential to the national interest. Second, many of the state corporations had become the economic fiefs of particular military-bureaucratic cliques, and the generals naturally refused to relinquish them.24

\section{Bureaucratic Capitalism}

The relationship between the bureaucratic state and capitalism can only partly be explained by the development of state capitalism. A more important factor has been the development of a phenomenon which will be referred to as bureaucratic capitalism. While state capitalism is the product of "rational" or "legal" bureaucratic authority (the officials involved are bound by a legal framework and do not appropriate the means of administration), bureaucratic capitalism is a product of patrimonial bureaucratic authority in which the demarcation between public service and private interest is at best blurred.

22J. A. C. Mackie, "The Indonesian Economy, 1950-1963," in Glassburner, ed., The Economy, pp. 16-69; and T. K. Tan, "Sukarnian Economics," in Tan, ed., Sukarno's Guided Indonesia, pp. 29-45.

${ }^{23}$ The shares of foreign capital as a percentage of total capital invested in the major sectors of the economy under both the foreign and domestic capital investment laws are as follows:

$\begin{array}{llll}\text { Agriculture and fisheries } & 33.5 \% & \text { Infrastructure } & 75.0 \% \\ \text { Forestry } & 59.3 \% & \text { Construction } & 19.0 \% \\ \text { Mining } & 96.0 \% & \text { Hotels and tourism } & 47.0 \% \\ \text { Industry } & 35.0 \% & \text { Others; mainly property } & 32.0 \%\end{array}$

(Compiled from Capital Investment Board data on investment under the foreign and domestic investment laws up to September 1973.) It must also be recognized that much of the capital invested under the domestic capital investment laws is foreign loan capital or foreign-financed equity. See the comments of Ir. Suhud at the American Indonesian Chamber of Commerce Seminar, New York, September 1975, for some idea of the extent of foreign banking participation in nominally domestic enterprise (Robison, "Capitalism," ch. 9, especially p. 444).

${ }^{24}$ As will be discussed below, various military factions secured hegemony over the operation of strategic state corporations, including the agricultural estates, Pertamina, and Bulog (the state food commodity board). 
Patrimonial bureaucracy in Indonesia has its origins in the precolonial Javanese kingdoms, where the king distributed appanage benefices to supporters, clients, and family. Bureaucratic office was itself an appanage which entitled the officeholder to make use of the office for private political and pecuniary ends.25

Such a system has been easily adapted to the capitalist environment of postcolonial Indonesia.26 Modern appanages take the form of bureaucratic offices distributed among civilian and military factions in the various governments. The most lucrative of such appanages are those offices with the power to allocate oil drilling leases, mining leases, forestry concessions, import and export licenses, government contracts for construction and supply, and state bank credit.

Bureaucratic capitalism was initially intimately associated with the growth of state corporations. When Dutch corporate interests in Indonesia were nationalized in 1957-58, most were put under military supervision. The military-dominated state trading companies virtually became agencies for the allocation of import licenses and distributorships to Chinese or foreign importers, who continued in practice to dominate the import sector.27 The new economic power of the military lay in controlling legal access to the market through state monopolies on various sectors of economic activity. The economic function of the military men running these enterprises was to generate finance for the political survival of factions, families, and even governments.

One of the major sources for such bureaucratic capitalism under the New Order has been the state oil corporation Pertamina. Although nominally a state corporation operating under ministerial control in pursuit of governmental policy, Pertamina was in fact until 1975 a fiefdom controlled by a military officer directly responsible to the President in pursuit of a variety of nongovernmental interests. Pertamina has only marginally been engaged in actual drilling. Instead, it has acted primarily as the authority allocating drilling leases to foreign companies. This combination of monopoly and lack of public

${ }^{25}$ Probably the best single analysis of the operation of the appanage in precolonial Java is Clifford Geertz, The Development of the Javanese Economy: A SocioCultural Approach (Cambridge, Mass.: Center for International Studies, M.I.T., 1956).

${ }^{26}$ Several writers have noted the similarities between the appanage system of the precolonial Javanese bureaucratic kingdoms and the relationships which exist between postcolonial party and military elites and the capitalist economy. Willner noted, for example,". . . the presence of silent Dutch and Chinese partnerships with whom the elite maintained a symbiotic relationship which supported the modern infrastructure whilst inhibiting its development by Indonesians"; Ruth A. Willner, The Neotraditional Accomodation to Political Independence: The Case of Indonesia (Princeton: Center of International Studies, 1966), p. 23. Anderson observes that "Corruption on a large scale typically takes the form of the allotting of the 'surplus' of certain key sectors of the economy to favored officials or cliques of officials, whether civilian or military. Rice collection, tin mining, oil production and distribution, and tax collection are only some of the areas in which officially supervised venality occurs." See Benedict R. O'G. Anderson, "The Idea of Power in Javanese Culture," in Claire Holt et al., eds., Culture and Politics in Indonesia (Ithaca: Cornel1 University Press, 1972), p. 49.

${ }^{27}$ See J. Panglaykim and I. Palmer, State Trading Corporations in Developing Countries (Rotterdam: Rotterdam University Press, 1969). 
accountability allowed Pertamina's directors to divert vast amounts of revenue from the state to the various military factions, in this way playing a central part in building the New Order power structure.28

Like Pertamina, Bulog has also been dominated by military officers responsible only to Suharto and has been concerned essentially with controlling access to the market. It is the sole purchaser of basic food commodities from both overseas and domestic sources and is the allocator of domestic distribution of these goods.29

On the whole, however, the rise of the New Order has made the private corporation the focal point of investment and production; and the dominant politico-bureaucratic groups quick1y established private companies as a means of enriching themselves. The largest of these "private" empires are:

\author{
Group \\ Department of Defense (Hankam) \\ Military commands
}

Army Strategic Reserve (Kostrad)

Special Operations (Opsus) associated groups

Siliwangi Division

Department of Interior

\author{
Company \\ P.T. Tri Usaha Bhakti \\ INKOPAD (Army) \\ INKOPAL (Navy) \\ INKOPAK (Police) \\ INKOPAU (Air Force) \\ Yayasan Dharma Putra \\ Pan Group \\ Pakarti Group \\ Berkat Group \\ P.T. Propelat \\ P.T. Poleko 30
}

Many of the directors and commissioners of the companies in these groups are men who were formerly, or indeed still are, senior officers within the finance-and-economy sections of particular military commands

${ }^{28}$ The information on Pertamina and Ibnu Sutowo is fragmented, and a definitive study of this crucial element in the political economy of Indonesia has yet to be made. The relationship between Pertamina and the state is treated to some extent in Robison, "Capitalism," pp. 248-58.

${ }^{29}$ Over the last decade both Pertamina and Bulog have been subjects of intense political debate focused on the question of accountability and of illegal channeling of state funds to centers of politico-bureaucratic power. This matter is discussed in ibid. Something of the struggle is reflected in the Report of the Commission of Enquiry into Corruption published in Sinar Harapan, July 18-23, 1970, in which considerable attention is given to the desirability of making Pertamina accountable. A close analysis of Bulog activities is to be found in the article "Ratu Pelita Sedang Gundah," Tempo, October 28, 1972.

$3^{\circ}$ Detailed tables on the major business groupings and their component companies, including shareholders, total equity, division of shares, directorships, and division of profits, are included in Robison, "Capitalism," Appendix B. The original sources for this information include Berita Negara Repubiik Indonesia, Tambahan: Perseroan ${ }^{2}$ Terbatas, Perseroan ${ }^{2}$ Firma atau Komanditer dan Perkumpulan ${ }^{2}$ Koperasi (henceforth $B N P T), 1960-75$; the Monthly Reports of the BKPMA; business and economic journals such as Business News; the weekly magazine Tempo; Jakarta newspapers; and extensive interviews with large numbers of Jakarta businessmen. 
(Finek). ${ }^{31}$ Part of their function is to channel the funds raised through their businesses to sustain existing politico-bureaucratic power-structures.

A variant form of bureaucratic capitalism involves the ownership of private companies, not by military commands, but by the families of powerful public figures. The most prominent of these business groups are those of the families of President Suharto, Sultan Hamengku Buwono, and Genera1 Ibnu Sutowo. 32

Unlike state capitalism or the capitalism of private entrepreneurs, which are generally devoted to the accumulation and productive investment of capital, bureaucratic capitalism is devoted to raising funds for directly political purposes. In a situation of intense competition for power between factions of the ruling military oligarchy, each must have access to its own sources of finance to bridge the gap between regular budgetary allocation and actual political need. ${ }^{33}$ In this sense, such bureaucratic capitalist activities parallel the front organizations and newspapers controlled by such centers of power as Hankam, Opsus, Bakin (State Intelligence Agency), and the Presidentia1 Palace.34 (Needless to say, the opportunities for the accumulation of massive personal wealth are also a major incentive for powerful officials to engage in economic activity, as is demonstrated by the extravagant life styles of high-ranking military officers and their families.)

Because the bureaucratic capitalists seldom have the capital, technology, know-how, or even the intention of becoming directly involved in investment and production, they must necessarily ally themselves with actual entrepreneurs, usually foreign or Chinese but occasionally asli. The terms of such alliances are an exchange of access to the market for a share of the product. These alliances work

${ }^{310 f f i c e r s ~ p r o m i n e n t ~(n o w ~ o r ~ i n ~ t h e ~ p a s t) ~ i n ~ p r i v a t e ~ m i l i t a r y ~ b u s i n e s s ~ g r o u p s ~}$ who were formerly attached to military finance or logistics units include:

General Sudjono Humardoni, now a director of P.T. Tri Usaha Bhakti and lynchpin of the Opsus business group. Formerly Deputy Chief of Finek, Diponegoro Division, and Deputy Chief of Finek, Army Central Command.

General Suryo, Head of Yayasan Dharma Putra and the state-owned Hotel Indonesia group. Former chairman of the State Auditing Office and personal presidential adviser for finance and the economy.

Kol. Hanafi Wiradireja, President-Director of the Siliwangi business group

P.T. Propelat. Former Chief of Finek, Siliwangi Division.

${ }^{32} \mathrm{Full}$ details on these and other family business groups are given in Robison, "Capitalism," Appendix B.

${ }^{33}$ The budgetary shortfall and the need to secure private sources of income for military units have been admitted by Admiral Sudomo (Tempo, June 7, 1975), General Hartono (Pedoman, September 30, 1969), and Admiral Harjono (Ekspres, October 3, 1970). The Armed Forces newspaper Angkatan Bersendjata (March 4, 1970) also dealt with this dimension of military financing.

${ }^{34}$ For example, the newspapers Suara Karya and Berita Buana are associated with Opsus. Angkatan Bersendjata is associated with Hankam. Ibnu Sutowo's personal gifts of mosques and sports stadia are well documented in the Jakarta press. The Commission of Enquiry into Corruption mentioned in their Report of July 1970 the need to regularize personal expenditure on gifts and scholarships by the President (see Sinar Harapan, July 18-23, 1970). 
not through public policy channels but through direct ties between particular centers of politico-bureaucratic power and particular business groups. The private business empires mentioned above are the instrumentalities of such alliances.

On a more specific level, what have been the institutional forms of this bureaucratic capitalism? One form, developed early on, has been monopoly control over segments of the import sector. Probably the most significant example of this form has involved the import of automobiles. In the $1950 \mathrm{~s}$ and early $1960 \mathrm{~s}$, the party factions which, at various times, secured control over the Department of Trade and consequently over the allocation of agency licenses, allocated sole agencies to client businessmen such as Hashim Ning, Dasaad, Haji Abdul Ghany Aziz, the Lubis family, Suwarma, and Panggabean. ${ }^{35}$ Under the New Order, however, the power centers have not allocated these agencies to clients but have instead established their own sole agency companies, often using Chinese partners as the actual operators. For example, Kostrad now owns the Volkswagen agency through its Yayasan Dharma Putra business group in partnership with the Chinese businessmen Sjafief Margetan and Sofyan Wanandi (Liem Bian Koen).36 Ibnu Sutowo owns the Mitsubishi agency Krama Yudha and is a partner with Hashim Ning in National Motors.37 In addition, he is a partner with Mercedes Benz in the Mercedes import, assembly, and distribution agencies P.T. German Motors and P.T. Star Motors.38 The President's brother, Probosutejo, is a part owner of the importer and distributor P.T. Multi France Motors. 39

More recently, however, import monopolies have been eclipsed to some extent by other forms of monopoly, notably lumber concessions. These concessions have been distributed among the various centers of politico-bureaucratic power, primarily the military commands. Thus the Hankam business group P.T. Tri Usaha Bhakti, in partnership with the business groups of particular regional military commands, controls at least fourteen concessions and timber companies. Others are owned by Kostrad, P.T. Poleko, the Presidential Palace, the Ibnu Sutowo family, and other assorted military groups. In every case the concession-holding company is established with minimal capital investment, rarely exceeding $\mathrm{Rp}$. 5 million (about US $\$ 12,500$ ). The concessions are transformed into operational companies only with the infusion of foreign and Chinese capital, which generally lifts the investment to the level of Rp. 1,000 million and above.40 This represents an Indo-

35Under PSI patronage, Hashim Ning was appointed President-Director of the state-owned Chrysler assembler I.S.C. Together with Dasaad, he secured the sole agency for the import and assembly of Fiats by P.T. Daha. Aziz secured the International Harvester, Lubis the Leyland, Suwarma the Mercedes, and Panggabean the Volkswagen sole agencies, respectively.

36For details, see BNPT, 1971 no. 591.

${ }^{37}$ BNPT, 1972 no. 408.

$38_{B N P T}, 1971$ no. 275 , and 1973 no. 935.

${ }^{39} B N P T, 1973$ no. 591.

${ }^{40}$ Some examples are: P.T. IRDA (Rp. 1 million) assumed a 25 percent share in the joint venture P.T. I.T.C.I. (Rp. 200 million); P.T. Sula (Rp. 2.5 million) assumed a 30 percent share in the joint venture P.T. Taliabu Luna (Rp. 800 million); P.T. Mulawarman Bhakti (Rp. 1 million) assumed a 44 percent share in the joint ventures P.T. Kayu Mulawarman (Rp. 560 million) and P.T. AC Timber Raya (Rp. 622 million). Full details of the forestry joint ventures are in Robison, "Capitalism," Appendix B, and pp. 260-61, 286-88. 
nesian contribution on the order of 0.5 percent. Yet typically, the military concession-holders end up with a 20-25 percent interest in the operational logging company. The central feature of the joint venture is the exchange of politically controlling economic concessions for financial reward. Analysis of the major joint ventures involving as $1 i$ partners reveals that the typical joint venture involves an asli shareholding of between 10 and 25 percent, with the asli partner usually a general or a member of a prominent political family. In his study of Japanese corporate investment in Indonesia, Yoshi Tsurumi concluded that 28 out of 30 asli partners were selected for their contacts within the government and that the equity of local partners in the larger ventures had been financed by the foreign partner. ${ }^{41}$ Many Indonesians have been scathing in their criticism of the role of asli partners and as $1 \mathrm{i}$ capital in joint ventures. Even the conservative Business News commented that:

. . the participation of local employees and capital in the joint venture should be a real fact and not merely a mask. The danger of shammed joint ventures is quite real, particularly if Japanese or local entrepreneurs wish only to look for the short term profits. Short-sighted Japanese entrepreneurs are quite happy because they have their own way of doing business, paying handsomely their local puppets. These local puppets have nothing to complain of; enough salary, living among high circles, known as local partners without doing any work. The losers are the general public who pay all the costs, just to enrich a small group of persons without creating any possibilities for the emergence of bona fide entrepreneurs in the future. ${ }^{42}$

Indeed, the asli partner, the bureaucratic capitalist, has no concern with the productive accumulation of capital. Consequently, he does not constitute a challenge either to the neopatrimonial state or to the domination of an undeveloped economy by foreigners and Chinese bourgeoisie; rather, he is essential to the survival of both.

It may be useful to illustrate this notion of bureaucratic capitalism by looking at the historical development of one particular, but very typical, bureaucratic capitalist group--the circle of the Suharto family.

President Suharto's business associations date back to the late $1950 \mathrm{~s}$, when he was commander of the Diponegoro Division. At that time the Division established a partnership with Chinese businessmen in the shipping companies P.T. Panggerang and P.T. Dwi Bhakti.43 The then Major Sudjono Humardani, from the Division's finance-and-economy

41Yoshi Tsurumi, A Report Submitted to the Harvard Advisory Group (Jakarta: Bappenas, October 1973), pp. 13-14.

42Business News (editoria1), February 3, 1973.

${ }^{43}$ BNPT, 1959 no. 826, and 1963 no. 263. An integral partner of these Diponegoro companies was the Chinese businessman Moh. (Bob) Hasan, whose extensive business group today links prominent military figures and their families with Chinese business interests. Note especially P.T. Karana and P.T. Wasesa, two shipping companies which once included General Gatot Subroto and his wife as shareholders and which allocate a portion of their profits to Mrs. Suharto's Yayasan Kartika Jaya. (BNPT, 1973 no. 662 , and 1968 no. 44.) 
section, served as official shareholder. Following his transfer to Kostrad in the early 1960s, Suharto became associated with the Kostrad business group, Yayasan Dharma Putra, together with his fellow officers Suryo and Sofyar.

While the early business activities of Kostrad involved the distribution of trading concessions in West Irian, Yayasan Dharma Putra moved into the field of joint ventures after 1965. The hub of Kostrad operations today is the Bank Windu Kencana, in which shares are held by Kostrad officers, while the operations are conducted by the Kencana group of Liem Sioe Liong. Other ventures include a logging company, an airline, a trading company, and an automobile import agency in partnership with Chinese businessmen of the Mantrust and Opsus groups.44

Suharto, however, moved on to become associated not only with Kostrad's business empire, but with a family empire of his own, the so-called Cendana group. This empire is essentially a nexus of junior partnerships in joint ventures with Chinese and foreign businessmen. The most important alliance exists with Liem Sioe Liong and his Kencana group which since 1965 has had the "good fortune" of obtaining the credit and licenses necessary to establish companies in banking, logging, trade, crumb rubber, flour milling, and cement. ${ }^{45}$ An illustration

${ }^{44}$ The major companies within the Yayasan Dharma Putra group include: P.T. Bank Windu Kencana (BNPT, 1968 no. 74); P.T. Seulawah Mandala Airlines (BNPT, 1971 no. 319); P.T. Garuda Mataram Volkswagen importers and assemblers (BNPT, 1971 no. 591); and P.T. Asia Veteran Development Logging Co. (BNPT, 1973 no. 21) .

${ }^{45} \mathrm{~A}$ brief outline of the Cendana group is as follows:

\section{Company}

P.T. Rumpun Estates

(BNPT, 1968 no. 1)

P.T. Kartika Chandra Hotel

(BNPT, 1970 no. 87)

P.T. Hanurata Logging

(BNPT, 1973 no. 320)

P.T. Waringin Kencana Trade \& Crumb Rubber (BNPT, 1970 no. 275)

P.T. Bogasari Flour Milling

(BNPT, 1970 no. 258)

P.T. Indonesia Cement

(BNPT, 1974 no. 273)

P.T. Kabel Metal

(BNPT, 1972 no. 503)

P.T. Semen Nusantara

(BKPMA, March 4, 1974)

Bank Ramayana

(BNPT, 1971 no. 604)

P.T. Mercu Buana Clove Import (BNPT, 1967 no. 137)
Suharto family and associates shareholding

Mrs. Suharto with Diponegoro officers and wives, $6 \%$ each

$100 \%$

$100 \%$

$15 \%$

$30 \%$

$7 \%$

$100 \%$
Chinese or foreign shareholding
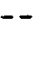

$-$

$-$

Liem Sioe Liong

Group $85 \%$

Liem Sioe Liong Group $96 \%$

Liem Sioe Liong Group $95 \%$ W. Germany $51 \%$

Japan $70 \%$ Ong Seng Keng and other Chinese $93 \%$ 
of the mechanics of these relationships is provided in the case of P.T. Bogasari, a Liem company which secured a monopoly position in flour milling and distribution for West Java together with credit of Rp. 2,800 million, although its initial capital was only Rp. 100 million. 46 In return, Liem's political patrons were well rewarded: the President's stepbrother, Sudwikatmono, was given the position of Senior Director and 4 percent of the shares, while 28 percent of the profits of Bogasari were to be divided between Kostrad's Yayasan Dharma Putra and Mrs. Suharto's Yayasan Harapan Kita.47

Apart from Sudwikatmono, who holds shares in a wide range of Liem companies, other members of the Suharto family, including the President's brother, Probosutejo, and Mrs. Suharto's brothers, Bernard Ibnu Hardoyo and Benny Jonosiswono, have shareholdings in a variety of foreign and Chinese companies. In each case the nature of their relationship to the companies appears to be similar to what we have seen in the Bogasari model. Probosutejo also owns P.T. Mercu Buana, a company built on a lucrative official monopoly of clove imports.

The pattern illustrated in the Yayasan Dharma Putra and Cendana cases is replicated elsewhere, notably in the business empires of Sultan Hamengku Buwono and General Ibnu Sutowo. Minority shareholding in the joint ventures with Chinese partners is the dominant form of such business activity; the companies thus formed invariably enjoy privileged access to state contracts, import and forestry concessions, and other monopolistic advantages. In these cases, too, the relationship between Chinese business groups and their political patrons, i.e., between Ibnu Sutowo and Tong Djoe, and Sultan Hamengku Buwono and Djamzu Papan, extends back several years.48 In general, the fortunes of

\footnotetext{
Suharto family and

\section{Company}

P. T. Mercu Buana Contractors (BNPT, 1973 no. 764)

P.T. Mercu Buana Chemicals (BNPT, 1973 no. 533)

P.T. Multi France Motors (BNPT, 1973 no. 591)

P.T. Buana Estate Property (BNPT, 1973 no. 649)

P.T. Kedawung Subur Glass (BNPT, 1974 no. 103)

${ }^{46}$ See Nusantara, December 11, 1971, and Indonesia Raya, November 3, 1972, for details on the establishment of Bogasari.

47BNPT, 1970 no. 258 .

${ }^{48}$ Tong Djoe, formerly of Palembang and now of Singapore, was associated with Sutowo during the latter's early years as director of Permina (one of the forerunners of Pertamina). By the late 1960s, Pertamina was purchasing and chartering ships from Tong Djoe, while Tong's Handara shipyard in Hong Kong was supplying Pertamina with barges and tugs. See Howard Dick, "The Indonesian Interisland Shipping Industry" (Ph.D. thesis, Australian National University, 1977), ch. 6. Sutowo and Tong Djoe are also private joint venture partners in a wide variety of companies including shipyards, a hotel, a travel company, and a livestock company. (See Robison,
} 
Chinese business groups have tended to rise and fall with those of their patrons; several of the major cukong (Chinese financiers) of New Order Indonesia were, previous to 1965, of regional rather than national importance, many of them coming from Semarang and Medan, where they were associated with either the Diponegoro Division or Kostrad.

An important question to be raised here is whether the movement of the families of powerful officials into business represents the beginnings of a consolidated ruling class. Will these families retain economic power after they lose control of political office and, consequently, of the power to allocate concessions of various types? Are they in the process of transferring their base of power from bureaucratic office to ownership of capital? For the most part the answer must be that they are not. Their business empires, as described above, remain nets of minority shareholdings in joint ventures in which their role is strictly political, and thus can not be sustained after loss of office. They will be of no value to joint venture partners once they are unable to mobilize licenses, credit, contracts, and other concessions.

There is some evidence, however, that the major families are now able to mobilize considerable amounts of privately owned capital. To the end of 1972, over Rp. 250 billion of investments had been made under the "capital-whitening" scheme whereby no explanation of the source of funds is required.49 Capital-whitening is a deliberate attempt to direct illegally accumulated money into productive investment. While much of this money may be that brought back into Indonesia by Chinese businessmen, it is reasonable to assume that the regulations have also been used to invest money derived from the exploitation of office.

There are several we11-known examples of investments by the major families and their clients financed by the private capital resources of prominent officials. One case is that of the P.T. Semen Cirebon cement works of the Suharto family client, Sukamdani Gitosarjono, who was able to demand and secure a 75 percent personal shareholding in a Rp. 18,000 million investment.50 The Sultan's client, Teuku Daud, as wel1 as Ibnu Sutowo and General Baramuli of the Poleko group, also fully own several substantial companies.51 However, the focus of

"Capitalism," p. 319 and Appendix B.)

The major Chinese partners in the Sultan's business group are Teddy Chandrajaya and Petrus Tirtajaya, both of whom are associated with the Putera group which in the 1950 s was part of the PSI/Bank of Indonesia cluster of enterprises. At that time the Sultan was working closely with Dr. Sumitro and others in the PSI to establish this partially state-owned core of companies. See Sutter, Indonesianisasi, pp. 981, 1054-64; and Robison, "Capitalism," pp. 302-8 and Appendix B. n. 15 .

${ }^{49}$ See the article, "Kredit PMDN--Antara Koneksi dan Investasi," cited above,

$500 \mathrm{n}$ P.T. Semen Cirebon, BKPMA, January 5, 1974. In an interview with the writer (September 12, 1974), Sukamdani expressed reluctance to enter joint ventures as a minority partner because, in his view, it resulted in dominance by the foreign partner. This view was also stated in an interview published in Suara Karya, June 22,1973 .

${ }^{51}$ The Teuku Daud empire embraces several large enterprises which are owned predominantly by Acehnese shareholders. These include P.T. Cita Engineering, P.T. Cita 
capital investment in fully owned companies has been primarily in real estate. This tendency is logical enough. Fall from office will not affect ownership of real property since retention of such property is not dependent on continuing control over allocation of concessions, nor does it involve reinvestment or production. The big families have moved into urban property and hotels in a substantial way just as they have, on a smaller scale, also moved into the purchase of private luxury homes, of resort housing, and of riceland in rural Indonesia.52 Thus, while these families may only have access to finance and control over concessions for the period during which they hold power, and therefore may enjoy only brief periods as joint venture partners, they are trying to build a long-term base of power for themselves upon land and property ownership. In doing this, however, they are constituting not a new bourgeoisie but a new class of rentiers. They are not challenging the dominance of foreign nor Chinese capital in trade, mining, or manufacture, but have become the main beneficiaries of the new opportunities for property speculation created by the expansion of capitalism.

\section{Client Capitalism}

A fourth form of asli business activity may best be described under the rubric of client capitalism. This form of enterprise involves individuals who have patrons in the politico-bureaucratic power group but do not themselves hold power or office. Like the bureaucratic capitalists, client business groups rely heavily on concessions and administrative monopolies. The major Chinese business groups associated with Sutowo, Suharto, the Sultan, Opsus, etc., are classic examples of such client capitalism. Several of the major client business groups, however, are asli.

But asli client capitalists have not achieved a really significant social and economic position for three basic reasons. First, the great bulk of politically controlled concessions have gone to foreign and

Crumb Rubber, P.T. Unatra Construction, and P.T. Unicon Property. Daud's early business career was with C.T.C., a PSI-sponsored state corporation. Today, Daud's business group is an integral component of a triangular business alliance between the Sultan, the Putera group, and his own Cita group (Robison, "Capitalism," pp. 302-8 and Appendix B). The core of Sutowo's group is the Bank Pasifik, fully owned by the Sutowo family (BNPT, 1973 no. 90). Although the trend for the Poleko group is also to move into joint ventures, several of its major companies (P.T. Poleko Trade, P.T. Sulinda, and P.T. Jagung) are fully owned by the Poleko family.

52Those cases where it is reasonably clear that the privately owned capital of officials and their clients is invested in business generally concern the hotel and property sector. Some examples are:

Probosutejo
Suharto family
Sukamdani
Ali Sadikin
Widodo Sukarno
Ibnu Sutowo
Sultan Group

P.T. Mercu Buana Real Estate

P.T. Rejo Sari Bumi Estates

Hotel Sahid

P.T. Pakuan

P.T. Mahkota

P.T. Indonesialand

P.T. Urecon Utama, P.T. Sovestco

It is common knowledge that officials and their families are the owners of a large proportion of the luxury Jakarta housing leased to foreign executives and officials. Although I have been unable to find documentary evidence, I am assured by authoritative sources that officials are moving into riceland ownership on a considerable scale, significantly changing the power structure in rural Indonesia. 
Chinese business groups. Particularly under the New Order, bureaucratic capitalists have preferred to link themselves with foreign and Chinese capital through joint ventures.53 Second, most clients have preferred to become brokers of concessions rather than using them as a form of capital on which to base a productive business structure. Given the unstable nature of power in Indonesia it is perhaps natural that opportunism and the search for quick profits should be preferred to long-term investment. Third, the fall of a patron is devastating to the asli client because in such cases the relationship between power and business is essentially personal. Although similar relationships exist between political patrons and foreign and Chinese business groups, the latter have independent sources of capital and independent control over trading and financial networks and thus may survive the fall of patrons. (They may indeed be sought out by the new power-holders.)

Client capitalism emerged first in the early 1950s, when political parties and factions exploited cabinet office to allocate licenses, concessions, and credit to asli businessmen associated politically with them. I have described earlier how established businessmen like Dasaad, Aziz, and Tamin expanded their business empires with the aid of privileged access to import licenses. In his work on the kretek industry, Castles aptly describes how the established manufacturers' association secured the clove import monopoly through the influence of Masjumi in the cabinet.54 Similarly the Batik Producers' Cooperative, GKBI, enjoyed a monopoly on the import of cambrics in the period of Masjumi ascendancy. 55

The vast majority of clients, however, were not established businessmen but simply political or family associates. While several of these, including Sudarpo, Kusmuljono, Hashim Ning, and Zainul Abidin, utilized politically derived concessions to establish genuine business enterprises, most simply sold their concessions to Chinese and foreign business groups. They became, in essence, brokers or fixers.

${ }^{53}$ The most important of the business alliances between asli politico-bureaucratic leaders and Chinese business groups are:

Center of Power

Palace

-Kostrad

-Cendana

Opsus

Sultan

Sutowo

The Government of Jakarta

\section{Chinese Business Group}

Kencana Group (Liem Sioe Liong) Bank Ramayana (Ong Seng Keng)

Pan Group (Mochtar Riady and Panglaykim) Pakarti Group (Liem Bian Kie and Liem Bian Koen) Berkat Group (Yap Swie Khie)

Putera Group (Chandrajaya)

Astra Group (William Suryajaya) Tunas Group (Tong Djoe)

Pembangunan Jaya (Ir. Tjiputera)

These are merely a selection of the most prominent alliances. Many such relationships exist right down to the village level. Substantiating data is too extensive to be listed here but may be found in Robison, "Capitalism," passim.

${ }^{54}$ Lance Castles, Religion, Politics and Economic Behavior in Java: The Kudus Cigarette Industry, Cultural Report Series (New Haven: Yale University, 1967).

55sutter, Indonesianisasi, pp. 679, 1051. 
Until 1965, such client capitalists were sustained chiefly by monopolies of import licenses, used to establish sole agency associations with foreign manufacturers. By the late 1950s, for example, PNI clients had secured a notable share of the most lucrative prizes within the import sector. Kusmuljono held the Krupp and De Havilland agencies, among others; Aziz, the International Harvester agency; and Dasaad, the Fiat Agency. Of the PSI clients, Hashim Ning had secured the Chrysler agency, while Sudarpo received several government import contracts.56

Under Guided Economy the picture changed somewhat. While Dasaad and Hashim Ning managed to maintain ties with the centers of power and even expand their collections of import monopolies, many former party client capitalists were eclipsed and the concessions they had held were transferred to newly emerging clients of the Presidential Palace. Markam and Aslam now dominated trade in rubber and other agricultural products. Panggabean and Suwarma secured the Volkswagen and Mercedes agencies. Bram Tambunan obtained a dominant position in the import of tires and textile machinery.

The fragility of the client system was clearly demonstrated by the fall of Sukarno and the emergence of the military government of Suharto. Old centers of patronage collapsed, and new forces moved in to control the various bureaucratic offices and thereby the power to allocate concessions. The trading empires of Aslam and Markam were handed over to the newly formed military trading company P.T. Berdikari.57 Another military business organization, INKOPAD, received the confiscated assets of Jusuf Muda Dalam and the P.T. Fiat Bluntas group. 58 The Mercedes agency was transferred from Suwarma to P.T. Berdikari and, upon the collapse of that group, to Ibnu Sutowo. Panggabean's Volkswagen agency, P.T. Piola, is now held by the Kostrad business group, Yayasan Dharma Putra. As we11 as losing their business assets, several major clients of the Guided Democracy period, including Aslam, Markam, Mardanus, and Bram Tambunan, were--1ike the major patrons (most notably Jusuf'Muda Dalam)--either jailed or exiled.

Up to 1965 , the relationship between patron and asli client was typically one in which licenses and concessions were allocated by patrons in return for money to underpin party and factional power. This is quite clear from evidence which came to light in the trials of Iskaq Tjokroadisurjo in the late 1950 s and Jusuf Muda Dalam in 1966

${ }^{56}$ Large numbers of party clients entered business in the Benteng period, including party officeholders such as Herling Laoh and Moh. Tabrani. Not only were import licenses selectively allocated, but government funds were used to bolster the deposits in private banks owned by major party figures, and government import contracts were subcontracted to selected clients. See J. Eliseo Rocamora, "Nationalism in Search of an Ideology: The Indonesian Nationalist Party, 1946-65" (Ph.D. thesis, Cornell University, pp. 180-92; and Sutter, Indonesianisasi, pp. 1020-35, 1053-54.

57See details on P.T. Berdikari and P.T. Bank Dharma Ekonomi (BNPT, 1966 no. 145 and 1967 no. 174).

${ }^{58}$ See the article "Bintang-Bintang Dalam Gelanggang Ekonomi," Tempo, February 3, 1973; and Harold Crouch, "The Indonesian Army in Politics" (Ph.D. thesis, Monash University, 1975), pp. 639-40. 
and 1967.59 After 1965, the emergence of the joint venture, which provided opportunities for power-nolders to associate directly with foreign or Chinese business, seriously hurt the asli broker. Most of the established asli client capitalists, especially those with origins in Sumatran Muslim entrepreneurial groups, either collapsed or stagnated. The Dasaad group is the most spectacular example of this change. Though Aziz still expanded his operations, he lost the big International Harvester agency. Several other businessmen who operated fully owned industrial enterprises up to 1965 , most notably Rahman Tamin, have been forced to seek foreign partners to survive. Almost all of the surviving asli client capitalists, including Harlan Bekti, Machdi, Zainul Abidin, and Widodo Sukarno, today function primarily as collectors of minority shareholdings in joint ventures.60

Although the generals of the New Order have typically preferred Chinese to asli clients and have presided over the rise of such important Chinese clients as Liem Sioe Liong (Kencana), William Suryajaya (Astra), and Panglaykim (Pan group), some new asli client groups have emerged. The Cendana client, Sukamdani, has enjoyed access to credit and financing on a scale which has lifted him from a minor business figure to the head of an empire which includes a Rp. 6,400 million hotel and a 75 percent share in a Rp. 18,000 million cement plant.61 Former PRRI/Permesta officers, led by Nicolas Sumual, have built a major business group, P.T. Konsultasi Pembangunan, around privileged access to forestry concessions and construction contracts.62 C1ients with important patrons are also much sought after by foreign investors as joint venture partners in a wide variety of enterprises, particularly in contracting and property.63

One of the most interesting examples of asli client capitalism is that of Pertamina's contractors. These include Siswono Judo Husodo, Fahmi Idris, Suryadharma Tahir, Ponco Sutowo, and several other sons

${ }^{59}$ The relationship between Jusuf Muda Dalam, Sukarno, and other major Guided Democracy political figures and their business clients was treated in detail in the Jakarta press in 1966 and 1967. See especially Warta Berita, January 7, 1967; Kompas, February 6, 1967; Sinar Harapan, February 16, 1967; see also Far Eastern Economic Review, Apri1 7, 1966.

${ }^{60}$ The most important surviving component of the Dasaad empire is a 20 percent partnership in a forestry joint venture (P.T. B.G. Dasaad Joint Venture). The Tamin family have been forced to seek joint venture partners in order to compete with the massive inflow of capital-intensive investment in the textile industry. Their P.T. Daralon is a joint venture, and they are seeking partners for P.T. Ratatex, once a giant national enterprise under Guided Economy. Much of this information comes from extensive interviews with asli businessmen including Eddy Dasaad, Darwis and Sofjan Tamin, Ali Noorluddin (Aziz), Harlan Bekti, Kusmuljono, and others during 1974.

${ }^{61}$ These are P.T. Sahid Hotel and P.T. Semen Cirebon.

${ }^{62}$ These are P.T. Taliabu Logging (BNPT, 1970 no. 26), P.T. Tartidmas Logging (BKPMA, October 26, 1971), P.T. Taliabu Luna Logging (BNPT, 1974 no. 28), and P.T. Cahaya Samudra Bulk Log Carrying (BKPMA, May 21, 1971).

${ }^{63}$ The data on these client groups is too extensive to list here. See the details on the groups of Widodo Sukarno, Sucipto Amidharmo, Tony Suleiman, Teuku Daud, and Sukamdani Gitosarjono in Robison, "Capitalism," Appendix B. 
of prominent officials.64 Their businesses are based upon access to Pertamina construction contracts awarded without tender. An insight into their operations is provided by the renegotiation of contracts following the downfall of Sutowo in 1975/76. It transpired that many of the contractors were in fact dealers in contracts, subcontracting to Chinese companies who carried out the actual work and provided the capital. It was also evident that much of their profits derived from the organized padding of contracts by Pertamina officials.65 Such a situation is reminiscent of the Benteng experience except that contracts have replaced import licenses as the commodity of brokerage.

As business in Indonesia has become increasingly structured around alliances between as1i politico-bureaucratic leaders and foreign or Chinese capital, the role of the asli client businessman has been to try to find a secure, if marginal, niche. Realizing that he is both dependent and dispensable, and that he can survive only by constant reaccommodation to changing political circumstances or by total integration with foreign or Chinese capital, he tends to seek short-term, high profit speculative gains while his good political fortune lasts.

\section{Conclusions}

The preceding analysis has shown that the power configurations among the ruling groups in Indonesia are related to the type of capitalism that has developed there. The generals must be understood as an integral component of that foreign-dominated capitalism. Not only are they bound to foreign and Chinese business groups in joint ventures and other less formal arrangements, but they preside over policies which guarantee the interests of their corporate partners. It is a relationship which, on the one hand, generates money for the political survival of the military bureaucracy and, on the other, provides foreign and Chinese business with access to lucrative markets and sources of cheap raw materials.

Bureaucratic capitalism has not generated a new independent asli bourgeoisie but is rather the means for sustaining a military bureaucratic state and providing the officeholders of that state with patronage for themselves, their families, and the political factions to which they owe their authority. Conflict among generals is therefore not only concerned with personalities and policies, but rather with the struggle for control of such lucrative appanages as Pertamina, Bulog, and Perhutani (forestry), and such strategic governmental departments as the ministry of trade, the customs service, and the Foreign Investment Board.

Looking at tensions within the Indonesian elite in terms of its relationship to capitalism helps to explain much of the political conflict that has occurred since the New Order came to power, including the demonstrations and arrests of 1970, 1974, and 1978. Prominent among the disaffected groups are the traditional Muslim bourgeoisie, both Outer Island traders and the Javanese textile, batik, and kretek

${ }^{64}$ Siswono is the son of Suwondo, former deputy mayor of Jakarta. Ponco Sutowo is the son of Ibnu Sutowo. Suryadharma Tahir is the son of General Tahir.

${ }^{65}$ See the article "Suara Kontraktor," Tempo, November 22, 1975. 
producers. Through trading associations and individual spokesmen they have protested against the economic policies of the government which have failed to give protection and subsidy sufficient to prevent largescale incursions into their traditional sectors of production by capital-intensive foreign and Chinese manufacturers.66 Through such newspapers as Nusantara and Abadi, both banned in January 1974, two power groups were singled out for criticism: the Bappenas economic planners who rejected protection and subsidy and encouraged large-scale foreign investment, and the generals, who, for personal and political gain, deployed the power of the state on behalf of foreign and Chinese business. Of particular importance was the widespread and bitter hatred expressed for the cukong.67 The attacks on the cukong were often explicit and detailed and reflect a continuing antagonism between asli Muslim and Chinese bourgeoisie which goes back to the days of the Sarekat Islam in the early decades of this century. Much of the political clout wielded by this sector of the opposition, such as it is, comes fron the fact that the asli merchant bourgeoisie is closely related to the opposition of modernist Islam to the abangan Javanese-controlled military bureaucratic state.

The other major current of opposition to the military bureaucratic state comes from intellectuals and students. Their concern is with government policies which produce foreign economic domination and intensify massive social inequality.68 Opposition to bureaucratic capitalism, generally expressed in terms of opposition to corruption, is based not only on moral abhorrence but on the conviction that much of the limited resources available for productive investment in Indonesia are being siphoned off by the generals for personal and political use.69 Student and intellectual oppositionists must also be understood in terms

\footnotetext{
${ }^{66}$ Because the national business association Kadin is now dominated by the generals and acts largely as an instrument of the administration (as did its predecessor under Guided Democracy, Bamunas), the most active associations are either regional or confined to particular economic sectors. Some of the most vocal are Perteksi (Indonesian Textile Producers' Association), Kopteksi (Indonesian Textile Cooperatives' Association), Ginsi (Indonesian Importers' Association), and the regional Kadin (Chambers of Commerce). Some of the more prominent individuals speaking on behalf of the asli entrepreneurs include Rachmat Mulyomiseno, Omar Tusin, Sutomo, and J. C. Tambunan, all leaders of declining asli business associations. The collapse of asli business has been widely discussed in the Jakarta press over the past ten years and the views of these individuals have become well known. See Robison, "Capitalism," ch. 9 .

67Nusantara, owned by the Acehnese businessman Teuku Hafas, was particularly persistent and explicit in describing the relationships between generals and cukong. See especially the issues of September 24, 1970, September 8, 1972, November 13, 1972, February 10, 1973, January 30, 1974, and January 31, 1974. The issue has also been discussed in the articles "Bintang-Bintang Dalam Gelanggang Ekonomi," Tempo, February 3, 1973; "Korupsi: Terasa Ada Terkatakan Tidak," Ekspres, June 27, 1970; and "Kaum Militer dalam Business," Ekspres, October 3, 1970.
}

${ }^{68}$ See Soedjatmoko, "International Relations in a New Era--Japan and the Economic Development of Asia" (paper given at Sophia University, Tokyo, October 29, 1973); and Sarbini, "Address to Japan-Indonesia Seminar on Nation Building," March 26, 1973, cited in Business News, March 28, 1973.

69 The material on corruption and reactions to corruption in the Jakarta press is extensive. See Robison, "Capitalism," pp. 354-70. 
of their social and political place in the capitalist structures in Indonesia. Before 1959, and even up to 1965, the intellectuals were to a large degree integrated in the power structure through the agency of the mass parties. After 1965, when hegemony was seized by the military, intellectuals ceased to play roles as politicians and were offered only those of technocrats and advisers, i.e., subordinate agents of the politico-economic alliance between the military and foreign and Chinese interests. Such roles in a neopatrimonial bureaucratic capitalist state offer 1ittle that is attractive to people proud of their technological, administrative, and managerial competence. Only this state's transformation into a regularized bureaucratic capitalist state would open up encouraging prospects for real political and administrative authority.

A serious challenge to the present ruling alliance would be posed if a strong national asli bourgeoisie emerged, able to insist on policies of protection and subsidy and the smashing of the cukong system. But it is clear that the traditional asli merchant bourgeoisie have little political muscle and a declining base of economic power. The government has avoided meeting their demands in any substantive way. As described in the previous pages, there is no evidence that the bureaucratic capitalists are significantiy transforming their base of power from bureaucratic authority to ownership of productive capital. Client capitalism has proven too fragile and dependent to produce a large, stable asli bourgeoisie. Although there are indications that elements in the Chinese bourgeoisie are seeking a commitment of the state to a national economy, their precarious social and political position means that they are uniikely to secure significant changes.70

The development of capitalism has produced competing interests among groups seeking to establish themselves as the new Indonesian ruling class. Looking at the conflicts within the elite in these terms provides a perspective which has been largely neglected in political analysis of Indonesia. Such a perspective enables us to view the military bureaucratic state within the framework of a peripheral economy as the logical synthesis of a precapitalist political culture with capitalist development in Indonesia, not simply as an aberration or a temporary obstacle to the normal developmental thrust of classical capitalism.

70The view put forward by the Center for Strategic and International Studies represents the opinion of a powerful section of the Chinese business community: that their survival is best guaranteed by accommodation with asli business groups under the umbrella of state protection against the multinational corporations. See $J$. Panglaykim, "Struktur Domestik Dalam Interdepensi Ekonomi Dunia," Analisa MasalahMasalah Internasional, 2, 12 (December 1973), pp. 37-44; and Kwik Kian Gie, "Foreign Capital and Economic Domination," Indonesian Quarterly, 3 (April 1975), pp. 39-72. 
